Indonesian Journal of Legality of Law
e-ISSN : 2477-197X
https://postgraduate.universitasbosowa.ac.id/

\title{
AKIBAT HUKUM PERKAWINAN SIRI TERHADAP HARTA KEKAYAAN DI DUSUN TAIPALAMPANG DESA BALUMBUNGANG KECAMATAN BONTORAMBA KABUPATEN JENEPONTO
}

\section{Legal Consequences of Unregistered Marriage towards Property in Taipalampang, Balumbungang Village, Bontoramba District, Jeneponto Regency}

\author{
Agusniar Basoddin ${ }^{1}$, Yulia A. Hasan ${ }^{1}$, Zulkifli Makkawaru ${ }^{1}$ \\ ${ }^{1}$ Program Studi Ilmu Hukum Program Pascasarjana Universitas Bosowa \\ Email: agusniarbasoddin@gmail.com
}

Diterima: 13 September 2021/Disetujui: 24 Desember 2021

\begin{abstract}
ABSTRAK
Penelitian ini bertujuan untuk mengidentifikasi tentang status harta pada perkawinan siri dan penyelesaian sengketa harta kekayaan pada perkawinan siri. Penelitian ini menggunakan metode kualitatif, yang bersumber dari data responden, pembagian angket dan wawancara serta bahan-bahan dari pustaka yang berlaku dan berkaitan dengan status harta kekayaan pada perkawinan siri yang terjadi di Dusun Taipalampang Kecamatan Bontoramba Kabupaten Jeneponto. Hasil penelitian ini menunjukkan bahwa fenomena perkawinan siri yang terjadi pada Dusun Taipalampang bisa menimbulkan berbagai macam permasalahan dari aspek hukum dan lingkungan masyarakat. Perkawinan siri menurut Pasal 2 ayat (1) Undang-Undang Perkawinan No 1 Tahun 1974, perkawinan yang sah adalah perkawinan yang dilakukan menurut hukumnya masing-masing agama dan kepercayaannya. Pada pasal tersebut undang-undang perkawinan menyerahkan syarat sahnya perkawinan dilihat dari sudut agama. pada perkawinan siri terdapat cacat administrasi karena pada pasal 2 ayat (2) UUP dijelaskan bahwa tiaptiap perkawinan dicatat menurut peraturan perundang-undangan yang berlaku sehingga apabila terjadi permasalahan pada sengketa perkawinan dapat diselesaikan dengan berdasarkan hukum yang berlaku. Diketahui bahwa pencatatan perkawinan merupakan salah satu bukti konkrit yang dapat digunakan untuk membuktikan apakah benar telah terjadi perkawinan, dengan adanya pencatatan juga memudahkan Pengadilan Agama menyelesaikan sengketa harta kekayaan apabila terjadi perceraian. Karena pada perkawinan siri tersebut sulit untuk menentukan status harta kekayaan dalam hukum apabila perkawinan tidak tercatat.
\end{abstract}

Kata Kunci: Perkawinan Siri, Status Harta Kekayaan, Dusun Taipalampang.

\begin{abstract}
This study aims to identify the status of property in unregistered marriage "nikah siri" and dispute resolution property on the unregistered marriage. This study uses a qualitative method, which is sourced from the data of respondents, the distribution of questionnaires and interviews as well as materials from the literature, which are valid and related to the status of property on unregistered marriage that happens in Taipalampang, Bontoramba District, Jeneponto Regency. The results of this study show that the phenomenon of "nikah siri" which happens in Taipalampang can cause a variety of problems from the aspect of law and society. Unregistered marriage, according to Article 2, paragraph (1) of the Marriage Law No. 1 Year 1974, a legal marriage is a marriage conducted according to the law of each religion and beliefs. In the chapter of the laws of marriage handed over the terms of the validity of a marriage is seen from the angle of religion. On Unregistered marriage, there are defects in administration because article 2, paragraph (2) UUP explains that every marriage is recorded according to the laws and regulations that apply so that in case of problems in a marital dispute can be resolved with the under applicable law. Be aware that the registration of marriage is one of the concrete pieces of evidence that can be used to prove whether the right has occurred to the marriage, with the recording also facilitating Religious Court resolve the dispute assets if they divorce. Because "nikah siri" is difficult to determine the status of the assets in the law if the marriage is unregistered.
\end{abstract}

Keywords: Unregistered Marriage, Status of Wealth, Taipalampang 


\section{PENDAHULUAN}

Persoalan perkawinan siri bukan hal baru bagi kalangan masyarakat Indonesia mulai dari kalangan menengah keatas hingga kalangan menengah kebawah biasa melakukan perkawinan siri, yang masih menjadi permasalahan hingga sekarang ini mengenai status hukumnya. Menurut Undangundang No 1 Tahun 1974 dalam Pasal 2 ayat (2) "tiap-tiap perkawinan dicatat menurut perundang-undangan". Akan tetapi menurut fiqih, perkawinan merupakan suatu akad yang terpenuhi syarat dan rukun dianggap sah meskipun tanpa adanya pencatatan. Dalam hal ini nampak ketidaksingkronan antara hukum formil dan hukum Islam. Pada salah satu pihak lebih ketertiban administrasi dalam sebuah perkawinan, disisi lain perkawinan merupakan acara yang sakral. Hingga akhirnya perbedaan tersebut muncullah istilah perkawinan siri atau perkawinan tidak tercatat. Perkawinan di bawah tangan atau siri, maksudnya ialah bahwa perkawinan itu tetap dilakukan dengan baik rukun-rukun maupun syarat-syarat yang telah ditentukan menurut hukum Islam, hanya pelaksanaannya tidak dilakukan melalui pendaftaran atau pencatatan di Kantor Urusan Agama yang mewilayahi tempat tinggal mereka(Agustina, 2015).

Pada awalnya hukum Islam tidak mengenal masalah administrasi perkawinan. Namun, seiring kompleksnya kehidupan manusia dan bersamaan dengan berdirinya negara bangsa, hukum perkawinan agama dituntut untuk menyesuaikan dengan tertib administrasi penyelenggaraan negara(Ilmiah et al., 2021). Pelaksanaan perkawinan pada umumnya didasarkan atas dasar saling menyukai, akan tetapi ada perkawinan yang meski calon mempelai sudah saling menyukai, namun perkawinannya dilaksanakan dengan tidak terang-terangan atau perkawinan dibawah tangan atau perkawinan siri atau 'nikah sirri', yaitu perkawinan yang dilakukan berdasarkan aturan agama atau adat istiadat dan tidak dicatatkan di kantor pegawai pencatat nikah (Adsdilah \& Ummu Siti, 2014). Istilah perkawinan siri atau nikah yang dirahasiakan memang sudah dikenal di kalangan para ulama. Hanya saja nikah siri yang dikenal pada masa dahulu berbeda pengertiannya dengan nikah siri pada saat ini. Dahulu yang dimaksud dengan nikah siri adalah perkawinan dengan rukun rukun perkawinan dan syaratnya menurut syari'I, hanya saja saksi diminta untuk tidak memberitahukan kepada khalayak ramai. Adapun perkawinan siri yang dikenal oleh masyarakat Indonesia sekarang ini adalah perkawinan yang dilakukan oleh wali atau wakil wali dan disaksikan oleh para saksi, tetapi tidak dilakukan dihadapan petugas pencatat nikah sebagai aparat resmi pemerintah atau tidak dicatatkan di Kantor Urusan Agama bagi yang beragama Islam dan di Kantor Catatan Sipil bagi yang tidak beragama Islam.

Dampak perkawinan siri tidak hanya mengenai status anak akan tetapi juga mengenai status harta kekayaan yang dihasilkan selama perkawinan. pada perkawinan tersebut istri dan anak berpotensi kerugian. Bilamana terjadi perceraian, maka isteri dan anak tidak bisa menuntut harta gono-gini yang telah diatur dalam hukum negara. Meskipun secara agama perkawinan tersebut sah namun perkawinan yang dilakukan diluar dari pengawasan pencatat nikah, tidak memiliki kekuatan hukum yang tetap dan tidak diakui dimata hukum negara. Hal inilah yang selalu berdampak negatif bagi isteri, lalu apakah hal tersebut benar-benar luput dari hukum?. Dalam hubungan suami isteri mempunyai hak dan kewajibannya masing-masing. Seorang Isteri bertanggung jawab mengurus rumahtangganya, mengurus suaminya dll sedangkan seorang suami berkewajiban menafkahi istrinya lahir maupun batin. Ketika ada kewajiban pasti ada hak yang harus dituai, seorang isteri berhak atas nafkah yang diberikan suaminya, baik secara lahir maupun batin, diperlakukan dengan baik dll. Dalam hal ini tentu kita ketahui bahwa walaupun hanya suami yang bekerja tetaplah seorang isteri mempunyai hak atas harta yang dihasilkan oleh suaminya. Harta kekayaan dalam keluarga disebut harta bersama yaitu harta yang dihasilkan selama perkawinan, baik hanya suami yang menghasilkan harta tersebut ataukah kedua-duanya. Namun, apabila terjadi perceraian, susah bagi seorang isteri untuk mendapatkan haknya terhadap harta tersebut, hal ini disebabkan tidak adanya aturan yang mengatur tentang status harta pada perkawinan tidak tercatat atau dibawah tangan. Dalam hal ini tidak sedikit masyarakat yang tinggal didesa menganggap sepele terkait masalah pencatatan perkawinan. Alasan-alasannya seperti faktor ekonomi ataupun alasan yang mendesak lainnya sehingga perkawinan dilangsungkan tanpa adanya pencatatan. Dengan adanya alasan - alasan tersebut akhirnya menimbulkan akibat hukum dimana status anak tidak jelas karena tidak adanya akta nikah.

Fenomena - fenomena perkawinan siri tidak hanya terjadi bagi kaum elit saja, terdapat fenomena yang sangat lazim terjadi disebuah kampung yaitu Desa Balumbungang lebih tepatnya di Dusun Taipalampang dan Dusun Parasangan Beru dimana masyarakatnya mayoritas melakukan perkawinan siri, mereka melakukan perkawinan siri selama sekian tahun, mereka hidup bersama dan memiliki keturunan dari perkawinan tersebut, mereka akan mencatatkan perkawinannya apabila ada kepentingan - kepentingan yang mereka tujukan. Di Dusun Taipalampang masyarakatnya berjumlah kurang lebih 360 orang (data Tahun 2020) dan mayoritas dari mereka melakukan perkawinan siri, ada yang masih dibawah umur namun sudah melakukan perkawinan ada juga yang melakukannya karena faktor ekonomi, mayoritas masyarakat Dusun Taipalampang kurang sadar akan pentingnya suatu pendidikan yang akhirnya mereka beranggapan bahwa akta nikah pada suatu perkawinan itu tidak penting, kurangnya kesadaran akan pentingnya suatu pencatatan menimbulkan pertanyaan bagaimana status anak dimata hukum apabila tidak dilakukannya suatu pencatatan, apa dampak - dampat pada perkawinan siri tersebut, dan untuk status harta yang mereka hasilkan bersama selama perkawinan nantinya bagaimana jika salah satu dari mereka ada yang menikah lagi, karena menikah lagi dengan status perkawinan sebelumnya tidak tercatat itu sangat lazim di kampung Dusun Taipalampang, dengan seenaknya meninggalkan itu menimbulkan luka bagi salah satu pasangannya bahkan anaknya yang tidak mengetahui permasalahan tersebut ikut menjadi korban dari perbuatan yang bukan dia lakukan. Di Dusun Taipalampang mayoritas masyarakatnya bekerja sebagai petani, suami istri bahkan anak ikut bertani dan atas hasil pertanian yang mereka kumpulkan nantinya statusnya bagaimana apabila salah satu dari pasangan suami isteri tersebut pisah tanpa adanya pencatatan perkawinan.

Perkawinan yang tidak tercatat jika dilihat dari segi hukum mempunyai kekurangan yaitu dalam hal administrasi sehingga perkawinan tersebut menimbulkan masalah bagi yang menjalaninya. Berbagai masalah yang timbul akibat perkawinan siri salah satunya mengenai harta kekayaan yang diperoleh pada perkawinan tersebut. Tanpa adanya surat atau bukti sah dalam perkawinan maka akan sulit membuktikan masalah harta antara suami dan isteri, hak waris antara anak dan orangtua. Akibat dijadikannya akta nikah sebagai alat bukti 
perkawinan, bagi mereka yang tidak mencatatkan perkawinannya maka segala macam akibat hukum yang terkait dengan peristiwa perkawinan tidak dapat diselesaikan dengan jalur hukum. Hal ini menimbulkan ketidakadilan bagi pihak perkawinan siri terutama menyangkut mengenai harta kekayaan."

\section{METODE}

Tipe dari penelitian ini adalah tipe penelitian empiris. Penelitian hukum empiris adalah suatu metode penelitian hukum yang menggunakan fakta - fakta empiris yang diambil dari perilaku manusia, baik perilaku verbal yang didapat dari wawancara maupun perilaku nyata yang dilakukan melalui pengamatan langsung. Penelitian empiris juga digunakan untuk mengamati hasil dari perilaku manusia berupa peninggalan fisik maupun arsip. Artinya, penulis akan mengkaji objek penelitian berdasarkan kenyataan - kenyataan yang terjadi dalam masyarakat yang dianggap relevan dengan permasalahan yang dihadapi.

Penelitian ini dilakukan di Dusun Taipalampang Desa Balumbungang Kabupaten Jeneponto. Teknik pengumpulan data dalam penelitian empiris terdapat 3 teknik yang digunakan, baik terdapat sendiri - sendiri atau terpisah maupun digunakan secara bersama - sama sekaligus. Ketiga teknik tersebut adalah wawancara, kuisoner dan observasi.

Data yang digunakan dalam penelitian ini meliputi 2 jenis data, yaitu: 1) Data Primer: Data yang diperoleh langsung dari lapangan berdasarkan responden dan narasumber. Pengumpulan data dilapangan dilakukan oleh peneliti dengan cara wawancara. 2) Data Sekunder: Pengumpulan data dalam penelitian ini dengan cara mempelajari dan mengumpulkan data yang berhubungan dengan objek penelitian. Data - data tersebut diperoleh dari buku - buku perpustakaan, peraturan perundang - undangan, browsing internet, jurnal dan dokumen - dokumen lainnya. Dalam hal ini peneliti mencari buku - buku yang dibutuhkan.

Data sekunder dikelompokkan menjadi 3 jenis bahan buku hukum, yaitu:

1) Bahan hukum primer

Bahan hukum primer adalah bahan hukum yang mengikat atau bahan yang berkait erat dengan permasalahan yang diteliti, meliputi:

a) Undang-undang Nomor 1 Tahun 1974 Tentang Perkawinan.

b) INPRES No. 1 Tahun 1991 Kompilasi Hukum Islam

c) UU No 16 Tahun 2019

2) Bahan Hukum Sekunder

Bahan hukum sekunder yaitu memberikan penjelasan mengenai bahan hukum primer yaitu:

a) Buku-buku yang berkaitan dengan judul dan permasalahan yang akan dikaji dalam penulisan tesis ini.

b) Hasil penelitian dan karya tulis ilmiah yang berkaitan dengan penulisan tesis ini.

c) Makalah - makalah seminar terkait dengan penulisan skripsi ini d) Jurnal hukum dan literature yang terkait dengan penulisan tesis.

3) Bahan Hukum Tersier

Bahan hukum tersier yaitu bahan yang memberikan petunjuk atau penjelasan terhadap bahan hukum primer dan bahan hukum sekunder, yaitu: Kamus Hukum, Kamus Bahasa Indonesia, Kamus Bahasa Inggris, dan Ensiklopedia terkait.

Adapun responden dan narasumber, yakni: 1) Masyarakat yang melakukan perkawinan siri yang berjumlah 12 orang. 2) Narasumber, Panitra Pengadilan Agama dan Kepala KUA Kecamatan Bontoramba. Teknik pengambilan sampel menggunakan pendekatan random sampling. Random Sampling adalah suatu cara pengambilan sampel yang memberikan kesempatan atau peluang yang sama untuk diambil kepada setiap populasi. Penelitian ini menggunakan random sampling yaitu dengan mengambil sampel dari beberapa masyarakat yang melakukan perkawinan siri untuk diambil kesimpulan. Langkah-langkah yang dilakukan dalam kegiatan analisis data penelitian adalah sebagai berikut: Data dan informasi yang telah dikumpulkan dari hasil penelitian, baik wawancara dengan instansi terkait maupun dari masyarakat kemudian dianalisis secara deskriptif kualitatif, yaitu suatu metode analisis dengan cara mengelompokkan dan menyeleksi data yang diperoleh dari penelitian menurut kualitas dan kebenarannya. Kemudian data tersebut dihubungkan dengan teori - teori dan peraturan perundang undangan yang diperoleh dari studi dokumen, sehingga diperoleh jawaban atas permasalahan dalam penelitian ini.

$$
\text { Rumus : }
$$

Keterangan :

$$
\mathrm{P}=\frac{f}{n} \times 100 \%
$$

$\mathrm{P}:$ Presentase

$\mathrm{f}$ : Frekuensi yang sedang dicari presentasenya

$\mathrm{n}$ : Jumlah Responden

\section{HASIL DAN PEMBAHASAN}

\subsection{Status harta kekayaan yang dihasilkan pada} perkawinan siri di Dusun Taipalampang.

Undang-undang Perkawinan tidak mengatur mengenai perkawinan siri. Hal ini menimbulkan beberapa pemahaman. Perkawinan adalah sah apabila dilakukan menurut masingmasing agama dan kepercayaan. Kesimpulan ini diambil karena banyaknya yang beranggapan bahwa perkawinan siri adalah perkawinan yang tidak pernah terjadi dikarenakan tidak dilakukannya suatu pencatatan.

Pada masyarakat yang melakukan perkawinan siri hal ini akan melahirkan berbagai permasalahan mengenai status harta dihasilkan selama perkawinan, apakah pada perkawinannya hanya akan berdampak ketidakadilan ataukah ada penyelesaian lain yang bisa ditempuh agar semua pihak mendapatkan keadilan. Robert Nozick dipandang sebagai penganut teori keadilan dengan pendekatan hak. Berbeda dengan Rawls yang memberikan ruang bagi keterlibatan pemerintah dalam mewujudkan keadilan distributif. Campur tangan pemerintah dalam mendistribusi keadilan harus diminimalisir karena tidak ada landasan moral yang 
membenarkannya(Budaya, n.d.), Berikut beberapa indikator pada status harta kekayaan pada perkawinan siri:

\section{Substansi Hukum}

Hukum ditempatkan sebagai aturan main dalam penyelenggaraan kehidupan berbangsa dan bernegara dengan tujuan hukum itu sendiri untuk menata masyarakat agar damai, adil dan bermakna. Hal ini berarti bahwa sasaran dari negara hukum adalah terciptanya kegiatan kenegaraan, pemerintahan dan kemasyarakatan yang bertumpu pada kepastian, kemanfaatan dan keadilan.

Salah satu peran strategis pemerintah dalam menata kehidupan masyarakat adalah dengan lahirnya Undangundang No. 1 Tahun 1974 tentang perkawinan. Ada beberapa jenis perkawinan yang dikenal di Indonesia salah satunya yaitu perkawinan siri atau perkawinan dibawah tangan yang biasa dilakukan masyarakat tanpa melakukan prosedur yang diatur dalam UUP dan aturan terbaru yaitu Undang-undang Republik Indonesia Nomor 16 Tahun 2019 tentang perubahan atas Undang-undang No 1 Tahun 1974 tentang perkawinan. Pada aturan tersebut terdapat poin-poin penting mengenai persyaratan seseorang apabila ingin melakukan perkawinan, salah satunya yaitu mengenai batas minimum usia seorang perempuan dan laki-laki ketika ingin melakukan perkawinan dimana aturan baru tersebut yang pada aturan lama di sebutkan bahwa usia perempuan yaitu 16 tahun dan usia laki - laki 19 Tahun, dalam aturan baru disebutkan untuk usia perempuan dan usia laki-laki yaitu 19 Tahun, tidak ada perbedaan usia terhadap keduanya.

Perkawinan siri merupakan perkawinan yang belum lengkap dalam hal mengenai administrasi atau pencatatan artinya bahwa terdapat masalah pada perkawinan tersebut dimana dijelaskan pada Pasal 2 ayat (2), "Tiap-tiap Perkawinan dicatatkan menurut peraturan perundangundangan yang berlaku."4 Sementara itu didalam Kompilasi Hukum Islam dijelaskan dalam Pasal 5, yaitu agar terjamin ketertiban Perkawinan bagi masyarakat Islam, setiap Perkawinan harus dicatat(Mudar, 2018). Dalam pasal Kompilasi Hukum Islam menentukan bahwa perkawinan adalah sah, apabila dilakukan menurut Hukum Islam sesuai dengan pasal 2 ayat 1 UU No. 1 Tahun 1974 yaitu perkawinan yang dilakukan menurut hukum agama. Dengan demikian pasal 4 Kompilasi Hukum Islam ini mempertegas bahwa perkawinan yang sah adalah perkawinan yang sesuai dengan pasal 2 ayat 1 UUP. perkawinan yang tidak terikat oleh hukum menyebabkan permasalahan yang setiap kali terjadi pada sengketa harta kekayaan dalam sebuah perkawinan. Padahal setiap orang berhak mendapatkan hakhaknya, hal ini sesuai dengan Undang-Undang Nomor 39 Tahun 1999 tentang Hak Asasi Manusia. Pasal 4, menyebutkan: Hak untuk hidup, hak untuk tidak disiksa, hak kebebasan pribadi, pikiran dan hati nurani, hak beragama, hak untuk tidak diperbudak, hak untuk diakui sebagai pribadi dan persamaan di hadapan hukum, dan hak untuk tidak dituntut atas dasar hukum yang berlaku surut adalah hak asasi manusia yang tidak dapat dikurangi dalam keadaan apapun dan oleh siapapun(Hasan et al., 2019). Kompilasi Hukum Islam (KHI) pada Pasal 5 dan Pasal 6 KHI yang mengatur agar dilakukannya pencatatan pernikahan oleh Pegawai Pencatat Nikah (PPN). Meskipun regulasi telah diatur sedemikian rupa namun tetap ada saja masyarakat yang tidak mencatatkan pernikahannya karena berbagai faktor sehingga pernikahannya menjadi nikah secara siri atau diam-diam. Nikah siri menjadi problematik dengan berbagai masalah hukum yang terjadi di masyarakat mengenai status hukum anak, harta benda, dan kedudukan suami istri itu sendiri(Agama et al., 2018).

Ada beberapa jenis perkawinan yang dikenal di Indonesia salah satunya yaitu perkawinan siri atau perkawinan dibawah tangan yang biasa dilakukan masyarakat tanpa melakukan prosedur yang diatur dalam UUP dan aturan terbaru yaitu Undang-undang Republik Indonesia Nomor 16 Tahun 2019 tentang perubahan atas Undang-undang No 1 Tahun 1974 tentang perkawinan. Pada aturan tersebut terdapat poin-poin penting mengenai persyaratan seseorang apabila ingin melakukan perkawinan, salah satunya yaitu mengenai batas minimum usia seorang perempuan dan lakilaki ketika ingin melakukan perkawinan dimana aturan baru tersebut yang pada aturan lama di sebutkan bahwa usia perempuan yaitu 16 tahun dan usia laki - laki 19 Tahun, dalam aturan baru disebutkan untuk usia perempuan dan usia laki-laki yaitu 19 Tahun, tidak ada perbedaan usia terhadap keduanya.

Perkawinan siri merupakan perkawinan yang belum lengkap dalam hal mengenai administrasi atau pencatatan artinya bahwa terdapat masalah pada perkawinan tersebut dimana dijelaskan pada pasal 2 ayat 2 UUP bahwa "tiap-tiap perkawinan dicatat menurut peraturan perundang-undangan yang berlaku". Dalam Negara yang teratur, segala hal-hal yang bersangkut paut dengan penduduk harus dicatat, kelahiran, perkawinan, kematian dan sebagainya. Hal ini sejalan dengan penjelasan pasal 2 dengan perumusan pada pasal 2 ayat 1 tidak ada perkawinan diluar hukum masingmasing agamanya dan kepercayaannya itu, sesuai dengan UUD Negera Republik Indonesia Tahun 1945. Dalam pasal Kompilasi Hukum Islam menentukan bahwa perkawinan adalah sah, apabila dilakukan menurut Hukum Islam sesuai dengan pasal 2 ayat 1 UU No. 1 Tahun 1974 yaitu perkawinan yang dilakukan menurut hukum agama. Dengan demikian pasal 4 Kompilasi Hukum Islam ini mempertegas bahwa perkawinan yang sah adalah perkawinan yang sesuai dengan pasal 2 ayat 1 UUP.

Selaras dengan teori keadilan, penulis menghubungkannya dengan hak seorang istri terhadap harta kekayaan yang dihasilkan dari perkawinan siri. Seorang istri mempunyai hak terhadap harta yang dihasilkan selama perkawinan walaupun hanya seorang suami yang bekerja mencari nafkah dan menghasilkan harta kekayaan, istri tetap mempunyai hak terhadap harta yang dihasilkan suaminya, dalam perkawinan suami dan istri mempunyai tanggung jawab masing-masing dalam sebuah perkawinan, diantaranya tanggung jawab seorang suami adalah menafkahi keluarga, menyiapkan tempat tinggal, memberikan pengamanan, mendidik anggota keluarga, berbuat baik pada keluarga. Sedangkan tanggungjawab seorang istri adalah melayani suami, menyenangkan hati suami, mengurus anak, mengurus rumahtangga dll. Tentu kita ketahui bersama bahwa ketika terdapat tanggungjawab tentu ada hak didalamnya, hak-hak seorang istri salah satunya mengenai harta yang dihasilkan selama perkawinan yang disebut harta bersama, meskipun harta bersama tersebut hanya suami yang bekerja dengan berbagai usahanya sedangkan istri hanya berada dirumah dengan tidak mencari nafkah melainkan hanya mengurus rumah tangga. Dengan demikian, seluruh harta yang diperoleh selama dalam ikatan perkawinan yang sah dianggap harta bersama suami isteri. Tidak dipersoalkan jerih parah siapa yang terbanyak dalam usaha memperoleh harta bersama tersebut. Suami maupun isteri mempunyai hak untuk mempergunakan harta bersama yang telah diperolehnya 
tersebut selagi untuk kepentingan rumah tangganya tentu dengan persetujuan kedua belah pihak..

\section{Kebiasaan Masyarakat}

Adapun mengenai judul penelitian yang dijadikan objek penelian yaitu Dusun Taipalampang, mengenai kaitan dari judul yang diangkat oleh penulis yaitu akibat hukum perkawinan siri terhadap status harta kekayaan yang dihasilkan selama perkawinan siri. Penulis pada penelitian ini telah membagikan angket dan disertai wawancara terhadap salah satu narasumber yang dianggap penulis mempunyai relevan atas judul tersebut, dalam penyelesaian permasalahan yang terjadi dalam kehidupan keluarga, secara tradisi atau kebiasaan masyarakat setempat selalu menyelesaikan permasalah secara kekeluargaan atau mediasi, seperti yang dikemukakan oleh salah satu narasumber. biodata singkat narasumber,Ibu Jumiati yang biasa akrab dipanggil Ibu Mati, melakukan perkawinan siri atau dibawah tangan pada usia 28 tahun, alasan melakukan perkawinan tersebut karena beliau menilai bahwa perkawinan tersebut adalah perkawinan yang wajar dan sah-sah saja. Hal ini dibuktikan dengan jawaban angket yang penulis bagikan kepada beliau yang memberikan jawaban bahwa perkawinan siri dilakukan karena tradisi turun temurun, salah satu alasan beliau juga dikarenakan orangtuanya tidak memberikan restu, perkawinan siri juga dianggap sebagai perkawinan yang lebih mudah dan tidak memerlukan persiapan yang sangat lama, pada perkawinannya tersebut mereka membeli sebidang tanah, tanah yang mereka beli belum mempunyai sertifikat tanah artinya mereka membeli tanah tersebut dibawah tangan.

Selanjutnya penulis bertanya mengenai status tanah tersebut apakah akan dikuasai satu pihak atau dibagi dua dan proses penyelesaiannya melalui jalur hukum atau sudah ada pembicaraan sembelumnya mengenai tanah tersebut dikarenakan perkawinan tersebut telah berakhir secara agama tanpa melalui isbat nikah, dan suami ibu Mati telah menikah kembali secara siri. Pada pertanyaan penulis tersebut beliau menjawab bahwa pada pembagian tanah tersebut sudah dibicarakan secara kekeluargaan dan hasil dari pembicaraan tersebut bahwa tanah yang mereka beli selama perkawinan akan diberikan kepada anak mereka, diketahui bahwa pada perkawinan tersebut ibu Mati mempunyai tiga orang anak dan tinggal bersama ibu Mati. Penulis lantas bertanya mengenai status tanah tersebut dikarenakan tanah tersebut tidak memiliki kekuatan hukum dan apabila ingin dibuatkan sertifikat, sertifikat tersebut akan diatasnamakan siapa berhubung anak-anak mereka masih dibawah umur. Pada pertanyaan tersebut beliau menjawab bahwa harta yang mereka hasilkan selama perkawinan Ibu Mati tidak akan mengklaim tanah tersebut sebagai kepemilikan pribadi akan tetapi tanah tersebut mengenai pembuatan alas hak atau sertifikatnya nanti beliau akan memikirkan apakah akan menunggu anak-anak mereka besar lalu dibuat sertifikat ataukah akan dibuatkan sertifikat dengan atas nama Ibu Mati untuk sementara menunggu anak-anak mereka cukup umur lalu memberikan kepada anak-anaknya.

Selanjutnya penulis kemudian menemui Pak Haerul Ahmad untuk mempertanyakan mengenai permasalahan yang penulis angkat. Menurut pendapat beliau selaku Panitera Pengadilan Agama Kabupaten Jeneponto bahwa perkawinans siri merupakan perkawinan yang sah secara agama namun tidak terdaftar oleh negara. Perkawinan siri tetap mempunyai akibat hukum asalkan perkawinan tersebut dapat dibuktikan, apakah benar perkawinan tersebut pernah terjadi dan mengenai harta yang dihasilkan selama perkawinan disebut denga harta bersama yaitu harta yang dihasilkan selama perkawinan, baik hanya suami yang bekerja atau keduaduanya dan apabila perkawinan siri tersebut berakhir tanpa adanya putusan pengadilan atau dengan cara agama, status harta dalam perkawinan tersebut dapat berakibat hukum dengan cara membicarakan secara kekeluargaan dan dibuatkan surat pernyataan atau datang langsung ke Pengadilan Agama dengan membawa bukti-bukti bahwa pernah terjadi perkawinan, salah satu cara dengan menghadirkan saksi-saksi pada saat dilaksanakannya perkawinan dan apabila ada foto perkawinan bisa juga digunakan dan mengenai pembuktian harta dalam perkawinan bisa dibuktikan dengan melampirkan tahun berapa pada saat harta tersebut dihasilkan sebelum perkawinan atau setelah dilangsungkannya perkawinan. Alangkah lebih baik melakukan isbat nikah terlebih dahulu untuk menguatkan bukti bahwa pernah terjadi suatu perkawinan.

Berdasarkan hasil penelitian, Penulis berpendapat bahwa menurut hasil wawancara dan pembagian angket mengenai status harta kekayaan pada perkawinan siri mempunyai akibat hukum yang berlaku bagi pelaku perkawinan siri hal ini sesuai dengan pasal 37 UU No. 1 Tahun 1974 yang berbunyi "Bila perkawinan putus karena perceraian, harta bersama diatur menurut hukumnya masing-masing" lebih jauh dalam penjelasan pasal 37 UU Perkawinan disebutkan bahwa " yang dimaksud dengan "hukumnya" masing-masing ialah hukum agama, hukum adat dan hukum-hukum lainnya. Pada penilitian tersebut hak-hak seorang isteri dan anak menjadi jelas mengenai harta walaupun hanya diselesaikan secara kekeluargaan namun dengan adanya hal tersebut keadilan bagi pelaku perkawinan siri atau dibawah tangan terhadap status harta kekayaan menjadi jelas dan dapat diselesaikan dengan baik. Selaras dengan teori keadilan distributif ialah keadilan yang berlaku dalam hukum publik yaitu berfokus pada distribusi, honor kekayaan dan barangbarang lain yang diperoleh oleh anggota masyarakat dengan mengesampingkan pembuktian matematis hal tersebutlah yang menjadi acuan bagi keadilan dalam pemenuhan hak-hak pada perkawinan siri atau tidak tercatat, sehingga dengan penerapan keadilan tersebut dapat memberikan keadilan bagi setiap masyarakat.

\section{Faktor Penyebab Perkawinan Siri}

Syarat-syarat perkawinan diatur mulai Pasal 6 sampai Pasal 12 UU No. I tahun 1974. Pasal 6 s/d Pasal 11 memuat mengenai syarat perkawinan yang bersifat materiil, sedang Pasal 12 mengatur mengenai syarat perkawinan yang bersifat formil(Faizal, 2016). Dusun Taipalampang terletak di Kecamatan Bontoramba Kabupaten Jeneponto dimana dareah tersebut termasuk wilayah yuridis Kantor Urusan Agama Kecamatan Bontoramba. Adapun untuk prosedur dan kelengkapan berkas pencatatan nikah di Kantor Urusan Agama Kecamatan Bontoramba, sebagaimana yang telah diberitahukan ibu Asma Hasan, adalah: 
1. Surat pengantar dari lurah/desa model (N1)

2. Permohonan kehendak nikah model (N2)

3. Persetujuan calon mempelai model (N4)

4. Surat ijin dari orangtua model (N5)

5. Fotocopy Akte Kelahiran

6. Fotocopy KTP

7. Fotocopy Kartu Keluarga

8. Pas foto $2 \times 3=4$ Lembar (latar biru)

9. Pas foto $4 \times 6=2$ Lembar (latar biru)

10. Fotocopy KTP Saksi 1 dan saksi 2

11. Surat keterangan mahar

12. Fotocopy KTP wali

13. Akte Cerai (asli)/ Surat keterangan kematian jika Duda/Janda

14. Surat izin komandan jika TNI/Polri

15. Surat izin kedutaan jika WNA

16. Fotocopy Passport jika WNA

Berdasarkan persyaratan yang dikemukakan diatas, pada perkawinan siri tidak memenuhi syarat yaitu pada bagian $1 \mathrm{~s} / \mathrm{d}$ 6, alasannya berbagai macam, pada poin $1 \mathrm{~s} / \mathrm{d}$ poin 4 dianggap menyusahkan sehingga pelaku perkawinan siri tidak mau mengurus dan memilih perkawinan yang tidak tercatat. Sedangkan pada poin 5 s/d 6 merupakan persyaratan administasi yg tidak bisa dipenuhi bagi pelaku perkawinan siri yang tidak memiliki akte kelahiran dikarenakan orangtua mereka dulu pun menikah secara siri sehingga tidak bisa mendapatkan akte kelahiran dan untuk poin 6 karena beberapa dari pelaku perkawinan siri masih dibawah umur sehingga belum bisa mempunyai KTP dan apabila dikaitkan dengan Pasal 7 ayat (1) UU No 16 Tahun 2019 Perkawinan hanya diizinkan apabila pria dan wanita sudah mencapai umur 19 (sembilan belas) tahun (Pemerintah et al., 2019).

Pada penelitian ini penulis melakukannya dengan cara wawancara dan membagikan angket. Pada kegiatan tersebut penulis mendapatkan atau memperoleh beberapa data mengenai faktor-faktor yang menyebabkan terjadinya perkawinan dibawah tangan atau nikah siri, sebagaimana jawaban yang diberikan oleh pelaku perkawinan siri. Terjadinya perkawinan siri disebabkan oleh beberapa faktor yaitu:

\section{Diagram 1}

Faktor Pendorong Perkawinan Siri di Dusun Taipalampang

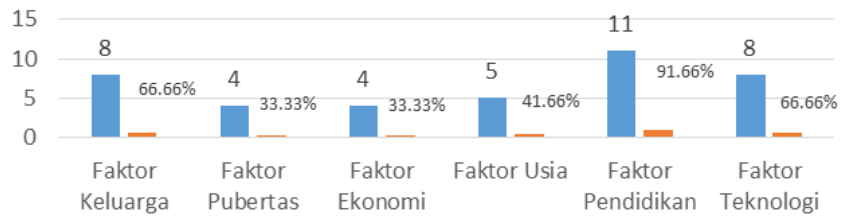

Gambar 1. Faktor pendorong perkawinan siri (Sumber data Tahun 2021)

Tabel 1

Faktor Keluarga pada perkawinan siri di Dusun Taipalampang

\begin{tabular}{clcc}
\hline No & $\begin{array}{c}\text { Jawaban } \\
\text { Responden }\end{array}$ & Frekuensi & Presentase \\
\hline 1 & Sangat Setuju & 1 & $8,33 \%$ \\
2 & Setuju & 7 & $58,33 \%$ \\
3 & Kurang Setuju & 3 & $25 \%$ \\
4 & Tidak Setuju & 1 & $8,33 \%$ \\
\hline \multicolumn{2}{r}{ Jumlah } & & $100 \%$
\end{tabular}

Sumber Data Tahun 2021

\section{a. Faktor Keluarga}

Faktor keluarga disini ikut mendorong terjadinya perkawinan siri oleh narasumber seperti yang dikatakan oleh ibu Sinar, beliau menuturkan bahwa ketika sudah ada keinginan untuk menikah, maka diberikan kebebasan untuk menikah oleh pihak keluarga dengan alasan daripada terjadi hal-hal yang tidak di inginkan lebih baik menikah saja. Dengan pernyataan narasumber tersebut menunjukkan bahwa pelaku perkawinan siri bukan hanya ingin menikah karena kemauan sendiri melainkan ada dorongan dari keluarga yang menginginkan adanya perkawinan untuk mencegah terjadinya hal-hal yang tidak di inginkan seperti hamil diluar nikah. Keluarga dalam hal ini mempunyai peranan penting dalam menentukan masa depan seorang anak.

Keinginan anak untuk berumah tangga memiliki dukungan dari pihak keluarga dengan mengijinkan mereka untuk menikah, selain ijin dari keluarga yang mendorong pelaku melakukan perkawinan siri, ternyata ditemukan kenyataan atau fakta bahwa biasanya orangtua pelaku perkawinan siri dulunya juga melakukan perkawinan siri, seperti ibu Jumasari orangtua dari Sri Putri Wahyuni yang mengungkapkan bahwa beliau juga menikah siri, sehingga apabila anak beliau ingin melakukan perkawinan tersebut adalah keadaan yang wajar menurut beliau.

Dalam keluarga juga beberapa dari pelaku perkawinan siri tidak mendapatkan restu dari orangtunya sehingga lebih memilih jalan tersebut sehingga mau tidak mau orangtua dari pelaku perkawinan siri akan tetap memberikan restu daripada harus menanggung malu.

\section{b. Faktor Puberitas}

Secara harfiah, pubertas berasal dari bahasa Latin pubescence yang berarti togrow hairy, tumbuhnya bulu-bulu", seperti bulu disekitar kelamin, ketiak, dan muka. Secara istilah, pubertas berarti proses pencapaian kematangan seksual dan kemampuan untuk berproduksi. Pubertas berarti, usia kedewasaan. Kata lain ini lebih menunjuk pada perubahan fisik daripada perubahan perilaku yang terjadi pada saat individu secara seksual menjadi matang dan mampu memberikan keturunan. Dalam kamus psikologi dijelaskan bahwa puberty atau pubertas adalah periode dalam kehidupan dimana terjadi kematangan organ-organ seks mencapai tahap menjadi fungsional. Terdapat variasi yang jelas sekali diantara individu-individu yang berbeda, akan tetapi pada umumnya usia bagi akhir periode ini diberikan sebagai berikut: untuk anak gadis ialah usia tiga belas tahun dan pada anak laki-laki empat belah tahun.

Tabel 2

Faktor Pubertasi Pada Perkawinan Siri Di Dusun Taipalampang

\begin{tabular}{clcc}
\hline No & Jawaban Responden & Frekuensi & Presentase \\
\hline 1 & Sangat Setuju & 0 & $0 \%$ \\
2 & Setuju & 4 & $33,33 \%$ \\
3 & Kurang Setuju & 6 & $50 \%$ \\
4 & Tidak Setuju & 2 & $16,66 \%$ \\
\hline \multicolumn{2}{c}{ Jumlah } \\
Sumber Data Tahun 2021
\end{tabular}

Alasan faktor pubertas dijadikan salah satu faktor yang diangkat oleh penulis berdasarkan pada keterangan beberapa narasumber yang diantaranya bernama Ibu Sana, Ibu Sarmila, Ibu Nurbaya, Ibu Ani. Berikut adalah hasil wawancara yang dilakukan oleh penulis. Narasumber pertama atas nama Ibu Sana, berdasarkan wawancara dan hasil angket yang 
dibagikan oleh penulis, narasumber tersebut berpendapat bahwa perkawinan siri atau perkawinan dibawah tangan merupakan perkawinan yang sah, narasumber yang pertama menikah siri di usia yang ke 20 tahun, usia yang sebenarnya sudah bisa melakukan suatu perkawinan, penulis berpendapat bahwa narasumber baru pubertas di usia tersebut sehingga tidak berfikir jangka panjang dan lebih memilih cara yang singkat untuk menikah tanpa melalui pencatatan. hal ini berdasarkan hasil angket yang di isi oleh narasumber dengan setuju bahwa perkawinan siri lebih mudah dilakukan dan tidak memerlukan persiapan yang panjang dan narasumber tersebut juga mengakui serta setuju bahwa narasumber menikah karena faktor pubertas.

Narasumber kedua atas nama Ibu sarmila, sama seperti Ibu Sana, Ibu sarmila juga menikah secara siri dan menganggap perkawinan tersebut adalah sah berdasarkan agama, ibu sarmila menikah pada usia 15 tahun, usia yang dalam hukum masih termasuk anak-anak, alasan ibu sarmila memilih menikah siri yaiitu faktor pubertas hal ini berdasarkan hasil angket dan wawancara yang dilakukan oleh penulis, beliau berpendapat bahwa yang dilakukannya merupakan hal yang wajar dikarenakan beberapa temannya juga melakukan hal yang sama.

Narasumber yang ketiga atas nama ibu Nurbaya, pada saat narasumber ketiga yang biasa disebut ibu Baya melangsungkan perkawinan usia beliau 18 tahun, usia yang dalam UUP sudah dianggap bisa melangsungkan perkawinan akan tetapi jika merujuk Undang-Undang No 16 Tahun 2019, beliau belum bisa melakukan perkawinan. Salah satu alasan yang dikemukakan narasumber kepada penulis yaitu karena pubertas sehingga hasrat beliau untuk menikah tidak bisa ditahan dan akhirnya memilih menikah siri. Menikah di kampung oranglain akan tetapi tetap meminta izin kepada orangtuanya. Dan dengan terpaksa orangtuanya memberikan izin daripada anaknya membuat malu, lebih baik diberikan restu, hal ini dikemukakan oleh bapak dari Ibu Baya.

Narasumber yang ke empat yang bernama Ibu Ani, Hubungan antara laki-laki dan perempuan umumnya menurut ibu ani adalah hubungan yang masih sangat asing dihidupnya, dikarenakan beliau tidak menyukai hubungan antara laki-laki dan perempuan atau biasa disebut dengan pacaran. Hal tersebut berubah ketika ibu Ani mengenal suaminya, rasa yang timbul didalam dada dan sangat menggebuh-gebuh atau faktor jatuh cinta membuat ibu Ani tidak bisa menahan hasrat tersebut, dari pada membuat malu keluarga, ibu Ani memilih melangsungkan perkawinan dikampung orang dan hal tersebut tentu saja dengan restu orangtuanya. Menikah secara agama dikampung oranglain, faktor pubertas atau puber dinilai menjadi salah satu penyebab ibu Ani mau melakukan perkawinan siri atau perkawinan dibawah tangan hal tersebut dikuatkan pada penilaian setuju pada angket yang dibagikan oleh penulis kepada narasumber.

Berdasarkan hasil wawancara, penulis berpendapat bahwa psikologis para pelaku perkawinan siri memberikan pengaruh yang sangat besar terhadap keputusan untuk menikah, kecenderungan masyarakat untuk melakukan perkawinan adalah adanya kebanggan dalam mendekatkan hubungan, faktor tradisi serta adat kebiasaan, kurangnya pengetahuan serta kesadaran masyarakat. Pada usia yang masih relatif muda atau masa pubertas rentan terhadap perilaku seksual, hal ini didukung dengan pola pikir secara emosional untuk melakukan perkawinan, mereka berfikir bahwa telah saling mencintai dan siap untuk melakukan perkawinan.

Walaupun perkawinan tersebut dilaksanakan secara sembunyi-sembunyi dan mengikuti hawa nafsu mereka tetapi pada saat akan dilangsungkan perkawinan narasumber tersebut meminta restu kepada kedua orangtuanya dengan bantuan perantara dari orang suruhan penghulu untuk memberitahukan bahwasanya anak mereka akan menikah apabila diberikan restu perkawinan akan dilaksanakan. Pada pernyataan tersebut penulis berpendapat bahwa perkawinan yang dilakukan oleh narasumber tetaplah sah karena sudah mendapatkan restu dari kedua orangtuanya dan dilangsukan berdasarkan hukum agama setempat. Selanjutnya narasumber juga berpendapat bahwa perkawinannya walaupun tidak dilakukan pencatatan pada saat menikah akan tetapi tetap mereka akan mendaftarkan perkawinan mereka.

\section{c. Faktor Ekonomi}

Faktor pendorong pernikahan siri lainnya adalah kondisi ekonomi masyarakat yang dapat dikatakan masih lemah. Masyarakat Dusun Taipalampang sebagian besar bermata pencaharian sebagai petani, dan buruh tani. Sebagian besar dari mereka menggarap lahan orang lain atau bukan milik pribadi. Bekerja sebagai petani dilakukan sejak pukul 6 pagi hingga pukul 5 sore, hasil yang mereka dapatkan pun hanya cukup untuk makan dan keperluan sehari - hari. Selain menjadi petani ada juga beberapa dari mereka yang memiliki tubuh masih kuat mengambil pekerjaan sampingan sebagai buruh bangunan. Mereka akan melakukan pekerjaan sebagai buruh bangunan apabila musim berganti menjadi kemarau, hal ini dikarenakan pada kampung tersebut hanya panen satu kali dalam setahun sehingga beberapa dari mereka melakukan beberapa pekerjaan sampingan dan salah satunya menjadi buruh bangunan.

Tabel 3

Faktor Ekonomi Pada Perkawinan Siri Di Dusun Taipalampang

\begin{tabular}{clcc}
\multicolumn{4}{c}{ Taipalampang } \\
\hline No & Jawaban Responden & Frekuensi & Presentase \\
\hline 1 & Sangat Setuju & 0 & $0 \%$ \\
2 & Setuju & 4 & $33,33 \%$ \\
3 & Kurang Setuju & 5 & $41,66 \%$ \\
4 & Tidak Setuju & 3 & $25 \%$ \\
\hline \multicolumn{2}{r}{ Jumlah } & & $100 \%$ \\
\hline
\end{tabular}

Sumber Data Tahun 2021

Hal serupa diungkapkan oleh ibu Rosmia, biaya daftar di KUA masih tergolong mahal menurut beliau yang hanya bekerja sebagai petani. Melakukan pekawinan secara agama menurut beliau sudah cukup dan sah, apabila mempunyai uang beliau akan mendaftarkan perkawinannya pada KUA. Ungkapan dari para narasumber menunjukkan bahwa salah satu faktor pendorong mereka melakukan perkawinan siri dikarenakan faktor ekonomi yang lemah sehingga tidak mampu untuk membayar biaya perkawinan yaitu sebesar Rp. 600.000 (berdasarkan informasi dari salah satu pegawai kantor KUA Kecamatan Bontoramba). 
Penuturan ibu Rosmia oleh narasumber yang lain tentang faktor pendukung mereka melakukan perkawinan siri menunjukkan bahwa ketidakmampuan mereka dalam kehidupan ekonomi sehingga membuat mereka melakukan perkawinan siri yaitu menikah secara agama yang biayanya jauh lebih murah tanpa harus mengurus surat-surat kelengkapannya. Faktor pendorong perkawinan siri dalam hal ekonomi ini tidak hanya faktor yang mendorong pelaku perempuan tetapi juga pelaku perkawinan siri laki-laki. Akan tetapi pada pelaku yang berjenis kelamin laki-laki enggan untuk dimintai keterangannya.

Perkawinan siri tergolong dalam tindakan yang cukup sulit bagi mereka yang ingin menikah. Keinginan menikah yang besar dan keluarga menyetujui namun terdapat kendala yang menyebabkan mereka mengambil keputusan untuk menikah secara agama saja atau yang popular dikenal dengan perkawinan siri. Desa Balumbungang yang lokasinya berada jauh dari pusat kota dan hanya memiliki beberapa sekolah dan minimnya lapangan pekerjaan membuat mereka dan keluarga mempunyai keinginan menikah di usia yang masih relatif muda. Keluarga mempelai yang usianya masih dibawah umur tersebut juga beranggapan bahwa jika anak - anak mereka sudah menikah, maka lepaslah tanggung jawab mereka terhadap anak mereka sehingga dapat mengurangi beban hidup keluarga seperti yang di ungkapkan oleh Ibu Jumasari orangtua dari Sri Putri Wahyuni, atas wawancara tersebut beliau menuturkan bahwa pekerjaan beliau dan suaminya hanyalah seorang petani, menyekolahkan anak-anak mereka hingga tamat SMA adalah suatu kesyukuran bagi mereka, akan tetapi apabila anak-anak mereka ingin menikah walaupun masih dibawah umur mereka tidak akan menghalangi kemauan anak-anak mereka hal tersebut dengan alasan daripada anak-anak mereka melakukan perbuatan yang tercela lebih baik menikah saja, dan tanggung jawabnya sebagai orangtua akan tergantikan nantinya oleh suami atau istri dari anak-anak mereka.

Hal tersebut memperlihatkan bahwa orangtua tidak mempermasalahkan usia anak yang masih muda, karena mereka merasa bahwa anak yang sudah menikah akan menjadi tanggungan suaminya sehingga dapat mengurangi beban hidup. Dari hasil wawancara diatas bahwa alasan untuk melakukan perkawinan siri karena juga pada awalnya tidak mempunyai biaya untuk menikah seperti pada umumnya, maka pada akhirnya memutuskan untuk melakukan perkawinan siri tanpa memikirkan apa akibat yang akan timbul dari perkawinannya tersebut.

\section{d. Faktor Usia}

Dalam UU No 16 Tahun 2019 diatur mengenai usia seseorang apabila ingin melangsungkan perkawinan yaitu laki-laki dan perempuan berusia 19 tahun, hal inilah yang menjadi permasalah beberapa masyarakat di Dusun Taipalampang. Disamping beberapa faktor yang sudah dijelaskan sebelumnya, salah satu faktor yang diangkat oleh penulis yaitu faktor usia, hal ini dikarenakan beberapa dari narasumber masih berusia remaja dan dalam hukum belum memenuhi syarat untuk menikah. beberapa dari narasumber ketika menikah masih berusia dibawah umur diantaranya ada 6 orang yaitu Ibu Nurbaya yang menikah siri pada usia 18 Tahun, Ibu Sarmila 15 Tahun, ibu Sri Putri Wahyuni 16 Tahun, Ibu Wanda 17 tahun, ibu Rosmia 13 Tahun, dan Ibu Nurung 18 Tahun. Karena faktor usia tersebut sehingga enggan melakukan perkawinan melalui proses pencatatan. Pada usia tersebut, beberapa dari mereka masih duduk dibangku sekolah sehingga apabila ingin menikah maka tidak akan diperbolehkan oleh kedua orangtua mereka, lalu diambillah jalan untuk menikah dikampung oranglain dan melangsungkan perkawinan dikampung tersebut. Apabila mereka sudah kabur dari rumah dan memilih menikah maka orangtua mereka mau tidak mau akan tetap memberikan restu atau izin.

Tabel 4

Faktor Usia Pada Perkawinan Siri Di Dusun Taipalampang

\begin{tabular}{clcc} 
No & Jawaban Responden & Frekuensi & Presentase \\
\hline 1 & Sangat Setuju & 0 & $0 \%$ \\
2 & Setuju & 5 & $41,66 \%$ \\
3 & Kurang Setuju & 3 & $25 \%$ \\
4 & Tidak Setuju & 4 & $33,33 \%$ \\
\hline \multicolumn{2}{c}{ Jumlah } & & $100 \%$ \\
\hline
\end{tabular}

Sumber Data Tahun 2021

Berdasarkan hasil penelitian diatas, penulis berpendapat bahwa faktor usia dan faktor pubertas mempunyai ikatan satu sama lain, pada faktor usia yang relatif masih dibawah umur untuk melakukan perkawinan, namun dalam hal faktor pubertas mempunyai pengaruh yang sangat besar untuk mendorong keinginan untuk menikah. Sehingga walaupun terkendala usia perkawinan tersebut tetap akan dilakukan karna usia remaja rentan di iringi dengan psikologi seksual yang berkaitan dengan puberty untuk memperkuat alasan kejiwaan dalam melakukan perkawinan.

\section{e. Faktor Pendidikan}

Selanjutnya faktor yang diangkat oleh penulis yaitu faktor pendidikan, hal tersebut berdasarkan data dari beberapa narasumber. Rendahnya pendidikan yang mereka tempuh sehingga kurang memahami tentang aturan-aturan apabila ingin menikah, seperti yang di ungkapkan oleh Ibu Rosmia. Ibu Rosmia menikah pada usia 13 tahun dan tidak menyelesaikan pendidikannya bahkan pada tingkat SD pun beliau tidak lulus. Berdasarkan angket yang penulis bagikan ibu Rosmia setuju bahwa anak yang masih dibawah umur sudah bisa melakukan perkawinan, itu adalah pemahaman ibu Rosmia pada saat akan menikah.

Narasumber selanjutnya yang penulis nilai karena rendahnya pendidikan sehingga lebih memilih menikah siri yaitu Ibu Nurbaya, pendidikan ibu Nurbaya hanya sampai pada tingkat SD saja dan tidak melanjutkan pendidikannya, rendahnya pemahaman betapa pentingnya pendidikan sehingga beberapa narasumber lebih memilih untuk tidak melanjutkan pendidikannya, sehingga berpengaruh terhadap rendahnya pengetahuan yang mereka miliki. Narasumber yang memiliki tingkat pendidikan yang rendah selanjutnya ada Ibu Wanda yang pendidikannya hanya sampai tingkat SMP dan memilih untuk tidak melanjutkan, selanjutnya ada ibu Sri Putri Wahyuni dan ibu Sarmila, sama seperti ibu Wanda hanya sampai pada tingkat SMP hal ini berdasarkan informasi dari narasumber tersebut.

Berdasarkan penelitian yang dilakukan penulis pada faktor pendidikan, penulis berpendapat bahwa faktor pendidikan masyarakat yang masih rendah yang mengakibatkan kurangnya pengetahuan masyarakat khususnya mengenai Undang-Undang Perkawinan No 1 Tahun 1974, pada pasal 2 ayat 2 dalam hal pencatatan.

Tabel 5

Faktor Pendidikan Pada Perkawinan Siri di Dusun Taipalampang

$\begin{array}{clcc}\text { No } & \text { Jawaban Responden } & \text { Frekuensi } & \text { Presentase } \\ 1 & \text { Sangat Setuju } & 0 & 0 \% \\ 2 & \text { Setuju } & 11 & 91,66 \%\end{array}$




\begin{tabular}{clcc}
3 & Kurang Setuju & 1 & $8,33 \%$ \\
4 & Tidak Setuju & 0 & $0 \%$ \\
\hline \multicolumn{4}{c}{ Jumlah } \\
\hline \multicolumn{2}{l}{ Sumber Data Tahun 2021 }
\end{tabular}

Sumber Data Tahun 2021

\section{f. Faktor Teknologi}

Faktor selanjutnya yaitu faktor teknologi, pertumbungan teknologi mempunyai beberapa dampak bagi penggunanya, jika kita salah menggunakan teknologi akhirnya akan berdampak buruk bagi penggunanya, dari 12 Narasumber ada 8 narasumber yang setuju bahwa fator teknologi menjadi salah satu penyebab dari alasan mereka memilih menikah secara siri. Teknologi dapat menghubungkan antara satu orang dengan oranglainnya, mudahnya berkenalan didunia social media membuka peluang bagi mereka memadu kasih, hasrat yang menggebuh gebuh. Pada narasumber dengan bantuan teknologi membuat mereka gampang terhubung satu sama lain. Faktor teknologi pula membuat mereka sering berbohong, sebut saja Ibu Sarmila, orangtuanya berharap Ibu Sarmila kesekolah akan tetapi faktanya ibu Sarmila malah bertemu dan memadu kasih dengan lelaki pujaannya yang sekarang menjadi suaminya. Hal tersebut membuktikan bahwa teknologi apabila salah digunakan maka akan berdampak buruk bagi penggunanya. Bukan hanya ibu Sarmila, tetapi beberapa narasumber yang lainpun menggunakan teknologi sebagai sarana untuk mengatur pertemuan mereka. Seringnya berkomunikasi lewat social media, telfonan membuat hasrat untuk saling memiliki semakin meningkat, daripada berbuat yang tidak-tidak, mereka memilih jalan yang untuk sebagian besar orang adalah jalan salah dengan cara kabur dari rumah dan menikah secara diam-diam.

Berdasarkan hasil penelitian penulis berpendapat bahwa faktor teknologi tidak dapat dipisahkan dalam era globalisasi, mudahnya seseorang mendapat informasi satu sama lain sehingga memudahkan dalam hal transaksi yang menjadi jalan utama terjadinya pertemuan sehingga berpeluang terbentuknya benih-benih perasaan yang menjadikan seseorang mengambil keputusan pintas untuk melakukan perkawinan tanpa melalui proses pencatatan.

Tabel 7

Rekapitulasi Keseluruhan Faktor Pendorong Perkawinan Siri di Dusun Taipalampang

\begin{tabular}{clcc}
\hline No & \multicolumn{1}{c}{ Faktor Pendorong } & Frekuensi & Presentase \\
\hline 1 & Faktor Keluarga & 8 & $66,66 \%$ \\
2 & Faktor Pubertas & 4 & $33,33 \%$ \\
3 & Faktor Ekonomi & 4 & $33,33 \%$ \\
4 & Faktor Usia & 5 & $41,66 \%$ \\
5 & Faktor Pendidikan & 11 & $91,66 \%$ \\
6 & Faktor Teknologi & 8 & $66,66 \%$ \\
\hline \multicolumn{1}{c}{ Jumlah } & & $100 \%$ \\
\hline
\end{tabular}

Sumber Data Tahun 2021

\subsection{Penyelesaian Sengketa Harta Kekayaan pada Perkawinan Siri di Dusun Taipalampang}

\section{Kekeluargaan}

Penyelesaian permasalahan secara kekeluargaan atau nonformal yang digunakan oleh sebagian besar masyarakat merupakan temuan lama atau berdasarkan kebiasaan masyarakat sejak nenek moyang bangsa Indonesia, hal ini juga yang digunakan pada sebagian besar masyarakat dusun Taipalampang pada penyelesaian masalah yang terjadi pada masyarakat tersebut salah satunya penyelesaian sengketa harta dalam perkawinan, baik perkawinan yang tercatat maupun perkawinan yang tidak tercatat atau siri. Pada penyelesaian secara kekeluargaan dinilai lebih cepat dibandingkan harus melalui jalur hukum. hal inilah yang menjadi alasan kenapa setiap permasalahan pada masyarakat tersebut lebih memilih menyelesaikan secara kekeluargaan. Cara ini juga menjadi kesempatan untuk menghidupkan kembali nilai-nilai kekeluargaan yang dilandasi persaudaraan sebagai dasar utama persatuan dan kesatuan Indonesia. Dengan penyelesaian secara kekeluargaan bukan hanya prosesnya yang lebih cepat selesai namun juga dapat meminimalisir gesekan antar masyarakat.

Pada penyelesaian sengketa harta kekayaan berdasarkan kekeluargaan penulis mengambil satu (1) pelaku perkawinan siri yang dianggap mempunyai relevan terhadap penelitian tersebut yaitu Ibu Mati, pada perkawinan ibu mati dengan mantan suaminya, mereka membeli sebidang tanah. Ibu Mati menikah tanpa melalui proses pencatatan sehingga untuk menyelesaikan permasalahan mengenai tanah tersebut tidak dapat melalui jalur hukum. Adapun prosedur penyelesaian secara kekeluargaan pada permasalahan tersebut dengan cara menghadirkan kedua belah pihak, baik dari pihak Ibu Mati maupun dari pihak mantan suami ibu Mati yaitu orangtua masing-masing, pembicaraan tersebut dilakukan secara internal dalam keluarga dengan mencatatkan keputusan hasil dari pembicaraan tersebut dengan membuat surat keterangan harta yang berisi bahwa harta tersebut akan diberikan kepada anak-anak mereka dengan bertanda tangan kedua belah pihak dan saksi-saksi yaitu orangtua dan tokoh masyarakat.

Berdasarkan penelitian tersebut terhadap penyelesaian sengketa harta kekayaan pada perkawinan siri, penulis mendatangi salah satu tokoh yang menurut penulis mempunyai relevan dengan permasalahan tersebut yaitu pak Sahani, beliau memberikan pendapat bahwa penyelesaikan secara kekeluargaan dianggap lebih baik dilakukan dibanding dengan jalur hukum dikarenakan perkawinan tersebut tidak tercatat sehingga penyelesaiannya dianggap rumit, terlepas dari perkawinan yang tidak tercatat bahwa harta yang dihasilkan atau tanah yang dibeli pada saat perkawinan tersebut merupakan tanah yang dibeli secara lisan atau dibawah tangan, hal ini memperkuat bahwa penyelesaian permasalahan tersebut lebih baik dilakukan secara kekeluargaan. Dalam penyelesaian secara kekeluargaan beliau memberikan saran atau pendapat bahwa perlu dihadirkan kedua belah pihak yaitu orangtua masing-masing hal ini untuk membicarakan secara internal mengenai masalah harta tersebut yaitu memisahkan yang mana harta bawaaan suami atau isteri dan harta yang dihasilkan bersama-sama selama perkawinan, hal itu bisa diambil kesimpulan pada musyawarah internal tersebut bahwa harta perkawinan arahnya akan kemana, akankah dijual lalu dibagi rata atau akan diwariskan kepada anak-anaknya.

Apabila pembicaraan tersebut sudah selesai maka dibuatlah surat pernyataan yang kemudian diketahui oleh pemerintah setempat. Apabila tidak bisa diselesaikan secara internal langkah selanjutnya yaitu melibatkan pemerintah 
setempat yaitu kepala Dusun atau kepala Desa sebagai pihak penengah atau pihak mediator untuk menyatukan pendapat, namun apabila tidak ada kesepakatan atau tidak bisa diselesaikan maka barulah ditempuh jalur hukum atau kepengadilan sebagai jalan akhir apabila tidak ditemukan titik temu. Penyelesaian secara kekeluarga tersebut dapat dibenarkan dalam hukum sehingga penyelesaian sengketa dapat memberikan keadilan bagi para pihak walaupun hanya diselesaikan secara kekeluargaan. Pada hasil penelitian tersebut penulis berpendapat bahwa penyelesaian secara kekeluargaan mengenai harta kakayaan pada perkawinan siri merupakan langkah yang tepat, dimana prosesnya lebih memberikan keadilan bagi para pihak terutama pihak istri dan anak.

\section{Jalur Hukum}

Prosedur penyelesaian sengketa harta kekayaan pada perkawinan dengan jalur hukum dapat dilakukan dengan mendatangi Pengadilan Agama apabila beragama Islam dengan mengajukan berkas ke Pengadilan. Cara ini dapat dilakukan apabila perkawinan tersebut tercatat. Berbeda hal dengan perkawinan yang tidak tercatat, Penyelesaian sengketa dengan jalur hukum merupakan langkah yang sangat sulit karena pada perkawinan siri tersebut tidak mempunyai kekuatan hukum atau tidak tercatat. hal inilah yang menjadi hambatan pada proses penyelesaian apabila ditempuh dengan jalur hukum. Walaupun hal ini bisa dilakukan namun hasilnya pun tidak memberikan keadilan bagi para pihak karena pada pasal 2 ayat 2 UUP dan pasal 4 Kompilasi Hukum Islam merupakan kendala bagi pelaku perkawinan siri apabila dilakukan penyelesaian dengan jalur hukum, maka sebelumnya harus membuktikan terlebih dahulu mengenai keabsahan perkawinan tersebut.

Tidak adanya aturan yang mengatur mengenai penyelesaian sengketa harta kekayaan pada perkawinan siri membuat langkah penyelesaian lebih memilih jalur kekeluargaan. Pengadilan Agama sebenarnya ada lembaga yang disebut dengan itsbat nikah (Penetapan Nikah) yang telah melembaga jauh sebelum lahirnya Undang-Undang Nomor 1 Tahun 1974, Undang-Undang Nomor 7 Tahun 1989 Tentang Peradilan Agama, dan terakhir Kompilasi Hukum Islam (Inpres Nomor 1 Tahun 1991) sebagaimana dinyatakan dalam Pasal 7 ayat (2) KHI bahwa dalam hal perkawinannya tidak dapat dibuktikan dengan akta nikah, dapat mengajukan itsbat nikahnya ke Pengadilan Agama(Wahyudi et al., 2009). Dan apabila permohonan isbat nikahnya dikabulkan maka perkawinan tersebut dapat menimbulkan akibat hukum. Namun,Dilakukan dengan isbat nikah pun tidak mengatur bahwa apabila dilakukan isbat nikah maka penyelesaian sengketa tersebut akan terselesaikan dimana pada Pasal 7 ayat (3) Kompilasi Hukum Islam juga menjelaskan, isbat nikah yang diajukan ke Pengadilan Agama terbatas mengenai halhal yang berkenaan dengan: adanya perkawinan dalam rangka penyelesaian perceraian; hilangnya akta nikah; adanya keraguan tentang sah atau tidaknya salah satu syarat perkawinan; adanya perkawinan yang terjadi sebelum berlakunya Undang-Undang No. 1 Tahun 1974 dan; Perkawinan yang dilakukan oleh mereka yang tidak mempunyai halangan perkawinan menurut Undang-Undang No. 1 Tahun 1974(cucu solihah, 2018). Mengenai penyelesaian berdasarkan jalur hukum pada perkawinan siri, penulis berpendapat bahwa hal tersebut kurang memberikan keadilan bagi para pihak terutama pihak istri dan anak, disamping prosesnya yang berbelit-belit dengan menghadirkan berbagai bukti perkawinan. Hal ini juga dapat menimbulkan gesekan antar pihak, baik pihak keluarga suami maupun istri, sehingga penyelesaian dengan jalur hukum dianggap kurang tepat.

Akan tetapi untuk solusi perkawinan siri/dibawah tangan dapat dilakukan upaya hukum yaitu mencatatkan perkawinan dengan cara itsbat nikah untuk memberikan kepastian hukum pada perkawinan siri maka akan ditempuh dengan permohonan itsbat nikah ke Pengadilan Agama atau melalui perantara Kantor Urusan Agama. Isbat nikah yang biasa disebut dengan pengesahan perkawinan adalah kewenangan Pengadilan Agama.

Berdasarkan ketentuan pasal 7 ayat (1) Kompilasi Hukum Islam (KHI) jo. Pasal 100 KUHPerdata, adanya suatu perkawinan hanya bisa dibuktikan dengan akta perkawinan atau akta nikah. Bahkan ditegaskan, akta nikah merupakan satu-satunya alat bukti perkawinan.

Adapun prosedur dari Isbat nikah yaitu:

a. Mendatangi kantor Pengadilan Agama setempat.

b. Surat keterangan dari KUA setempat yang menyatakan bahwa perkawinan tersebut belum dicatatkan.

c. Surat keterangan dari kepala desa/lurah yang menerangkan bahwa pemohon telah menikah.

d. Fotocopy KTP pemohon isbat nikah

e. Membayar biaya perkara

f. Menunggu panggilan sidang dari pengadilan

g. Menghadiri persidangan

h. Berkas lain yang akan ditentukan hakim dalam persidangan

i. Putusan pengadilan.

Penyelesaian sengketa dengan jalur hukum pada perkawinan siri atau tidak tercatat dapat dilakukan namun terlebih dahulu alangkah lebih baik dilakukan isbat nikah sebagai upaya hukum karena kita ketahui bahwa lemahnya perkawinan siri dalam hal administrasi yang menjadi kekurangan apabila lebih memilih penyelesaian dengan jalur hukum.

\section{KESIMPULAN DAN SARAN}

Hasil penelitian dan pembahasan dapat disimpulkan bahwa Status harta pada perkawinan siri didusun Taipalampang apabila dilihat dari sudut pandang Undangundang maka hal tersebut tidak dapat berakibat hukum dikarenakan terkendala dalam hal administrasi sesuai dengan Pasal 2 ayat 2 UUP dan kaitannya pada Pasal 4 KHI, hal inilah yang menjadi hambatan apabila ingin menyelesaikan sengketa harta kekayaan dengan jalur hukum. Sehingga, pada penyelesaian sengketa mengenai harta tersebut lebih memilih dengan cara kekeluargaan yaitu menghadirkan kedua belah pihak dan membicarakan permasalahan tersebut lalu dibuatkan surat perjanjian mengenai hasil dari kesepakatan tersebut sehingga kedua belah pihak mendapatkan keadilan dalam hal pembagian harta kekayaan pada perkawinan siri. Dengan adanya hasil kesepakatan tersebut dapat menimbulkan akibat hukum terhadap satu sama lain. Penyelesaian yang sering dilakukan dengan cara kekeluargaan menimbulkan Kurangnya kesadaran masyarakat mengenai pentingnya suatu pencatatan sehingga penyelesaian konflik keluarga hanya bisa dilakukan secara internal dan apabila dibiarkan hal itu berdampak bagi menurunnya kualitas kesadaran masyarakat kedepannya karena menjadikan masyarakat lebih apatis terhadap aturan formil yang merupakan aturan pokok hal administrasi. 


\section{DAFTAR PUSTAKA}

Addilah, \& Ummu Siti. (2014). Implikasi Hukum Dari Perkawinan Siri Terhadap Perempuan dan Ana. Implikasi Hukum Dari Perkawinan Siri Terhadap Perempuan Dan Anak, 7(1), 1-30.

Agama, S. P. P., Aldia, R., Ta, P., Cahyono, A. B., \& Prihatini, F. (2018). Isbat Marriage to Siri Marriage ( Study of Religious Court Decisions ) Abstract yang dikabulkan oleh Pengadilan Agama. Untuk itu perlu dilakukan studi lebih lanjut mengenai pengaturan tentang Isbat Nikah di Indonesia dan juga konsep pernikahan siri pada . 1974(3).

Agustina, E. (2015). Akibat hukum hak mewaris anak hasil perkawinan siri berbasis nilai keadilan. Jurnal Pembaruan Hukum, II(2), 381-390. http://jurnal.unissula.ac.id/index.php/PH/article/view/13 72

Boedi Abdullah. (2011). Pengantar Hukum Keluarga. Bandung. CV Pustaka Setia. Bandung.

cucu solihah. (2018). Dampak Kebijakan Isbat Nikah Terhadap Perkawinan Siri. Jurnal Hukum Adan Pembangunan, 9(4).

Faizal, L. (2016). Akibat Hukum Pencatatan Perkawinan. Asas: Jurnal Hukum Dan Ekonomi Islam, 8(2).

Hasan, Y. A., Studi, P., Hukum, I., Pascasarjana, P., Bosowa, U., Ilmu, P., Universitas, H., \& Hakim, P. (2019). Pengadilan Negeri Makassar Analysis of Judging Determination in Granting of Different Marriage Licenses in Makassar Court. 2(1), 13-17.

Ilmiah, J., Pancasila, P., Kewarganegaraan, D. A. N., \& Artikel, R. (2021). Prosedur Ideal Pengakuan Bagi Anak Luar Hasil Perkawinan Ideal Procedures For Recognition For Outside Children After. 6, 1-10.

Makkawaru, Z. (2019). Perlindungan Hukum Ekspresi Budaya Tradisional Upaya Pengelolaan Aset Kekayaan Intelektual Bangsa.

Mudar, A. nadir. (2018). Fenomena Itsbat Nikah Terhadap Perkawinan Yang Dilakukan Setelah Terbitnya UndangUndang Nomor 1 Tahun 1974 Tentang Perkawinan (Studi Di Pengadilan Agama Andoolo). Zawiyah: Jurnal $\begin{array}{lll}\text { Pemikiran } & \text { Islam, } & \text { 4(2), }\end{array}$ https://doi.org/10.31332/zjpi.v4i2.1026

Mukti Fajar dan Yulianto Achmad, Dualisme penelitian Hukum Empiris dan Normatif, Pustaka Pelajar,2010. hlm. 161

Pemerintah, P., Indonesia, R., Daerah, P. K., Rahmat, D., Yang, T., Esa, M., \& Indonesia, P. R. (2019). Lembaran Negara. 42.

Rachmadi Usman. (2006). Aspek-aspek Hukum Perorangan dan Kekeluargaan di Indonesia. Sinar Grafika. Jakarta. 